\title{
Pembelajaran Matematika Melalui Pendekatan Open-Ended dengan Bantuan Power Point untuk Meningkatkan Kemampuan Pemecahan Masalah di Masa Pandemi
}

\author{
Tiara Yulita ${ }^{1}$, Hardi Suyitno ${ }^{2}$, Sugiman $^{3}$ \\ ${ }^{1}$ Program Studi Ilmu Aktuaria, Fakultas Bisnis dan Ilmu Sosial, Universitas Binawan, \\ ${ }^{2,3}$ Program Studi Pendidikan Matematika, FMIPA, Universitas Negeri Semarang, \\ Jl. Kalibata Raya - Dewi Sartika No 25-30, Jakarta Timur, DKI Jakarta, Indonesia \\ tiara.yulita@binawan.ac.id
}

\begin{abstract}
During the pandemic, all learning activities especially mathematics learning are not carried out in schools but at homes. One of the mathematical skills that need by students is problem-solving ability. The 2013 revised 2018 curriculum applies that student must be actively involved in problem solving and be able to interpret, understand the competencies that are guided by teacher. The results of the National Examination for Junior High School show that student's problem-solving abilities are still relatively low even though the questions are routine questions, while nonroutine questions (open-ended problems) are rarely used when presenting questions. One of the efforts to overcome this is using an open-ended approach with the help of power-points as a supporting media in online learning during the pandemic. The population taken was the 7th grade students of SMP Negeri 1 Comal, while method used was a quasi-experimental design with a research design in the form of a pre-test post-test control group where two experimental groups which were selected by random sampling. From the rightside average similarity test and normalized gain test, it shows that learning with open-ended and power-point approach is effective for improving student's problem-solving abilities and is better than the expository learning model.
\end{abstract}

Keywords: Math Learning, Problem Solving, Open-Ended, Power Point, Pandemic.

\begin{abstract}
Abstrak
Di masa pandemi, seluruh kegiatan pembelajaran khususnya pembelajaran matematika tidak dilaksanakan di sekolah melainkan dirumah masing-masing atau secara daring. Salah satu keterampilan matematika yang perlu dikuasai peserta didik adalah kemampuan pemecahan masalah. Kurikulum 2013 revisi 2018 juga menerapkan bahwa peserta didik harus terlibat secara aktif dalam pemecahan masalah serta dapat menafsirkan dan memahami kompetensi yang dibimbing oleh guru. Hasil UN peserta didik SMP/MTs/SMPT menunjukan bahwa kemampuan pemecahan masalah peserta didik masih tergolong rendah padahal soal tersebut merupakan soal rutin, sedangkan soal non rutin (openended problems) sudah jarang digunakan pada saat penyajian soal. Salah satu upaya untuk mengatasi hal tersebut yaitu menggunakan pendekatan open-ended dengan bantuan power point sebagai media penunjang dalam pembelajaran daring di masa pandemi. Populasi yang diambil adalah peserta didik kelas VII SMP Negeri 1 Comal, sedangkan metode yang digunakan adalah quasi experimental design dengan rancangan penelitian berupa pre-test post-test control group dimana terdapat dua kelompok uji coba yaitu kelompok eksperimen dan kontrol yang dipilih secara random sampling. Dari uji kesamaan rata-rata pihak kanan dan uji gain ternormalisasi menunjukan hasil bahwa pembelajaran dengan pendekatan open-ended dan power point efektif untuk meningkatkan kemampuan pemecahan masalah peserta didik dan lebih baik dibanding model pembelajaran ekspositori.
\end{abstract}

Kata kunci: Pembelajaran Matematika, Pemecahan Masalah, Open-Ended, Power Point, Pandemi

Copyright (c) 2021 Tiara Yulita, Hardi Suyitno, Sugiman

$\square$ Corresponding author: Tiara Yulita

Email Address: tiara.yulita@binawan.ac.id (Jl. Kalibata Raya - Dewi Sartika No 25-30, Jakarta Timur)

Received 31 Mei 2021, Accepted 16 Juni 2021, Published 17 Juni 2021

\section{PENDAHULUAN}

Sejak Desember 2019, terdapat suatu jenis virus corona baru yaitu Severe Acute Respiratory Syndrome Coronavirus 2 atau SARS-CoV-2 atau 2019-nCoV yang terkonfirmasi pertama kali di Wuhan, China. World Health Organization (WHO) mengumumkan nama penyakit tersebut adalah Covid-19 (World Health Organization, 2021). Dalam waktu yang sangat singkat penyakit Covid-19 ini menular dari satu orang ke orang lain dan telah menyebar hingga ke seluruh dunia. Pandemik yang sudah berlangsung selama 
satu tahun ini sangat berpengaruh terhadap semua orang dan semua bidang, salah satunya bidang pendidikan. Menteri Nadiem Anwar Makarim telah menerbitkan Surat Edaran Nomor 4 Tahun 2020 pada Satuan Pendidikan dan Nomor 36962/MPK.A/HK/2020 tentang Pelaksanaan Pendidikan dalam Masa Darurat Coronavirus Disease yang memberikan arahan bahwa kegiatan belajar mengajar oleh peserta didik dilakukan secara daring (online) dalam rangka pencegahan Covid-19 tidak terkecuali dengan pembelajaran matematika.

Menurut penelitian yang dilakukan oleh Pusat Penilaian Pendidikan Kemendiknas terhadap hasil Ujian Nasional tahun 2019 tentang statistik nilai per mata pelajaran peserta didik pada jenjang pendidikan SMP/MTs/SMPT terlihat bahwa pelajaran matematika memiliki kategori kurang serta mempunyai rata-rata paling rendah dibandingkan mata pelajaran yang lain yaitu senilai 42,94. Data ditunjukkan pada gambar berikut (Pusat Penilaian Pendidikan, 2019).

\begin{tabular}{|c|c|c|c|c|c|}
\hline \multicolumn{6}{|c|}{$\begin{array}{c}\text { STATISTIK NILAI } \\
\text { TAHUN PELAJARAN 2018/2019 }\end{array}$} \\
\hline Jenis Satuan Pendidikan & \multicolumn{2}{|l|}{ SMP/MTS/SMPT } & Jumlah Satuan Pendidikan & \multicolumn{2}{|l|}{166} \\
\hline Status Satuan Pendidikan & $N \& S$ & & Jumlah Peserta & \multicolumn{2}{|l|}{21.345} \\
\hline \multirow{2}{*}{ STATISTIK } & \multicolumn{4}{|c|}{ Per Mata Pelajaran } & \multirow{2}{*}{$\begin{array}{c}\text { Semua } \\
\text { Mata Pelajaran }\end{array}$} \\
\hline & BAHASA INDONESIA & BAHASA INGGRIS & MATEMATIKA & IPA & \\
\hline Kategori & Cukup & Kurang & Kurang & Kurang & Kurang \\
\hline Rata-Rata & 66,84 & 46,20 & 42,94 & 46,44 & 50,61 \\
\hline Terendah & 18,0 & 20,0 & 12,5 & 15,0 & 74,0 \\
\hline Tertinggi & 98,0 & 98,0 & 100,0 & 97,5 & 389,5 \\
\hline Standar Deviasi & 13,64 & 12,07 & 13,48 & 13,11 & 42,94 \\
\hline
\end{tabular}

Gambar 1. Statistik Nilai Per Mata Pelajaran Peserta Didik SMP/MTs/SMPT

Menurut Emilya, Darmawijoyo, \& Ilma (2013) di dalam matematika terdapat tiga aspek yang harus dikuasai oleh peserta didik yaitu pemahaman konsep, penalaran dan komunikasi, serta pemecahan masalah. Kenyataan yang terjadi peserta didik hanya menguasai aspek pemahaman konsep saja, dimana dalam proses belajar mengajar sangat sedikit guru yang menggunakan pertanyaan-pertanyaan untuk menumbuhkan pemecahan masalah. Bahkan dalam Ujian Nasional, soal yang diberikan adalah bentuk pilihan ganda dan merupakan soal rutin, sehingga tanpa mencaripun peserta didik dapat menjawab soal dengan cara menebak. Hal ini menyebabkan kurangnya kreatifitas dan daya nalar peserta didik.

National Council of Teacher Mathematics menyebutkan bahwa salah satu keterampilan matematika yang merupakan tujuan dan sarana utama dalam pembelajaran matematika adalah kemampuan pemecahan masalah matematika (mathematics problem solving) (Allen et al., 2020). Banyak ahli yang mengatakan pentingnya belajar pemecahan masalah dalam matematika. Hudojo (2005) menyatakan bahwa mengajarkan penyelesaian masalah kepada peserta didik, memungkinkan peserta didik itu menjadi lebih analitik di dalam mengambil keputusan di dalam hidupnya. Dengan perkataan lain, bila peserta didik dilatih menyelesaikan 
masalah, maka peserta didik itu akan mampu mengambil keputusan. Bahkan menurut Hendriani, Melindawati, \& Mardicko (2021) keterampilan pemecahan masalah merupakan kompetensi utama yang dibutuhkan di era ini. Polya (2004) menyatakan bahwa pemecahan masalah matematika merupakan suatu usaha untuk menemukan jalan keluar dari suatu kesulitan dan mencapai tujuan yang tidak dapat dicapai dengan segera, sehingga diperlukan suatu langkah-langkah dalam pemecahan masalah yaitu (1) memahami masalah, (2) merencanakan pemecahan masalah, (3) melakukan perhitungan, (4) memeriksa kembali hasil dan menyimpulkan jawaban.

Dalam proses belajar mengajar, masalah-masalah matematika terbuka (open-ended problems) jarang disentuh pada saat penyajian soal. Akibatnya open-ended problem sering dianggap salah soal atau soal yang tidak lengkap. Padahal, open-ended problem menuntut peserta didik untuk berkreatifitas dan lebih bernalar dalam menjawabnya daripada hanya mengingat prosedur baku dalam menyelesaikan suatu masalah, hal ini sesuai dengan tujuan Permendiknas Nomor 19 Tahun 2007.

Untuk mengatasi hal tersebut, di dalam kurikulum yang berlaku sekarang, difokuskan dalam pembelajaran matematika hendaknya pendekatan permasalahan terbuka. Salah satu solusinya yaitu melaksanakan pembelajaran dengan pendekatan open-ended. Pembelajaran dengan pendekatan open-ended merupakan pembelajaran yang menggunakan masalah terbuka dan memberikan keleluasaan berpikir secara aktif dan mampu mengundang peserta didik untuk menjawab permasalahan melalui berbagai cara atau berbagai jawaban sehingga memacu perkembangan matematikanya.

Menurut Bruner ada tiga tahap perkembangan kognitif, yaitu tahap enaktif, tahap ikonik, dan tahap simbolik (Rifa'i \& Anni, 2012).Taraf berpikir peserta didik SMP/MTs/SMPT masih berada pada tahap operasi ikonik yaitu suatu tahap pembelajaran sesuatu pengetahuan di mana pengetahuan itu direpresentasikan (diwujudkan) dalam bentuk bayangan visual (visual imaginery), gambar, atau diagram, yang menggambarkan kegiatan kongkret, sedangkan substansi matematika bersifat abstrak (Hawa, 2014). Sehingga pemanfaatan power point sesuai kemajuan teknologi diduga dapat membantu proses pembelajaran matematika khususnya untuk meningkatkan kemampuan pemecahan masalah peserta didik SMP/MTs/SMPT. Selain hal tersebut karena pembelajaran matematika pada era pandemi ini diadakan secara daring maka power point merupakan salah satu media pendukung yang sangat sesuai dalam pembelajaran.

Berdasarkan penjelasan diatas, tujuan penelitian ini adalah untuk menganalisis keefektifan pembelajaran matematika dengan menggunakan pendekatan open-ended dan dibantu oleh power point sebagai media teknologi untuk meningkatkan kemampuan pemecahan masalah peserta didik SMP/MTs/SMPT di masa pandemi.

\section{METODE}

Penelitian ini menggunakan pendekatan kuantitatif dengan penelitian eksperimen, dimana suatu hal dapat diteliti adanya pengaruh atau tidak dalam penelitian tersebut. Pemahaman konsep dasar penelitian kuantitatif tidak dapat dipahami dari satu aspek tertentu melainkan beberapa aspek yaitu pendekatan, 
metode, data, dan analisis (Widodo, 2017). Jenis penelitian yang digunakan dalam penelitian ini adalah quasi experiment research. Penelitian ini bukan merupakan eksperimen murni tetapi seperti murni atau seolah-olah murni karena berbagai hal terutama berkenaan dengan pengontrolan variabel kemungkinan sukar sekali dapat digunakan eksperimen murni (Syaodih Sukmadinata, 2007). Desain dalam penelitian ini menggunakan rancangan berupa pre-test post-test control group dimana terdapat dua kelas yaitu kelas eksperimen yang mendapat pembelajaran dengan pendekatan open-ended dengan bantuan power point dan kelas kontrol yang mendapat model pembelajaran ekspositori yang dipilih secara acak. Menurut Sugiyono (2014) adapun desain penelitian pre-test post-test control group mempunyai rancangan sebagai berikut.

Tabel 1. Desain Penelitian Pre-test Post-test Control Group Design

\begin{tabular}{|l|l|l|l|}
\hline $\begin{array}{l}\text { Pengambilan } \\
\text { Sampel }\end{array}$ & \multicolumn{1}{|c|}{ Tes Awal } & \multicolumn{1}{|c|}{ Variabel } & \multicolumn{1}{|c|}{ Tes Akhir } \\
\hline $\begin{array}{l}\text { Random } \\
\text { sampling }\end{array}$ & $\begin{array}{l}\text { Pre-test kelompok } \\
\text { eksperimen }\left(O_{1}\right)\end{array}$ & $\begin{array}{l}\text { Variabel bebas berupa pembelajaran } \\
\text { dengan pendekatan open-ended } \\
\text { dengan bantuan power point }(X)\end{array}$ & $\begin{array}{l}\text { Post-test kelompok } \\
\text { eksperimen }\left(O_{2}\right)\end{array}$ \\
\hline $\begin{array}{l}\text { Random } \\
\text { sampling }\end{array}$ & $\begin{array}{l}\text { Pre-test kelompok } \\
\text { kontrol }\left(\mathrm{O}_{3}\right)\end{array}$ & - & $\begin{array}{l}\text { Post-test kelompok } \\
\text { kontrol }\left(\mathrm{O}_{4}\right)\end{array}$ \\
\hline
\end{tabular}

Adapun langkah-langkah yang dilakukan dalam penelitian ini adalah sebagai berikut.

1. Menentukan populasi, yaitu kelas VII A - VII H SMP Negeri 1 Comal sebanyak 319 orang.

2. Menentukan sampel dari populasi tersebut secara cluster random sampling, terpilih 40 anak pada kelas VII B sebagai kelompok eksperimen dan 39 peserta didik pada kelas VII A sebagai kelas kontrol.

3. Menyiapkan perangkat pembelajaran.

4. Menyusun instrumen penelitian.

5. Melakukan uji coba instrumen pre-test dan post-test kemampuan pemecahan masalah pada kelas uji coba instrumen yang sebelumnya telah diajarkan materi yang sesuai dengan kelas eksperimen dan kontrol, yaitu kelas VII C sebagai kelas uji coba instrumen pre-test dan VII D sebagai kelas uji coba instrumen post-test.

6. Data hasil uji coba instrumen pre-test dan post-test tersebut dianalisis untuk mengetahui validitas, realibilitas, indeks kesukaran, dan daya pembeda. Setelah dianalisis pada faktor-faktor tersebut, diambil soal yang sesuai kriteria untuk digunakan dalam pre-test dan post-test pada kelas eksperimen dan kontrol.

7. Melakukan pre-test kemampuan pemecahan masalah terhadap peserta didik pada kelas eksperimen dan kontrol.

8. Data hasil pre-test tersebut diuji normalitas, homogenitas, dan kesamaan rata-rata hasil belajar. Dari beberapa uji tersebut diketahui bahwa kelas eksperimen dan kontrol berasal dari populasi yang berdistribusi normal dan homogen karena variansnya sama, serta kelas eksperimen dan kontrol mempunyai kemampuan pemecahan masalah awal yang sama sebelum diberi perlakuan. 
9. Memberi perlakuan pada kelas eksperimen dengan menggunakan pembelajaran dengan pendekatan open-ended dengan bantuan power point, sedangkan kelas kontrol menggunakan model pembelajaran ekspositori.

10. Melakukan post-test kemampuan pemecahan masalah terhadap peserta didik pada kelas eksperimen dan kontrol.

11. Menganalisis data hasil post-test dari kelas eksperimen dan kontrol.

Variabel penelitian yang digunakan ada tiga yaitu variabel bebas, terikat, dan kontrol. Variabel bebas dalam penelitian ini adalah pembelajaran dengan pendekatan open-ended dengan bantuan power point dan model pembelajaran ekspositori. Sedangkan variabel terikatnya yaitu kemampuan pemecahan masalah matematika peserta didik kelas VII SMP/MTs/SMPT, dan variabel kontrolnya adalah materi, buku referensi yang dipakai peserta didik, guru, ruang kelas, zoom, g-meet, kurikulum, dll.

Pengambilan data pada penelitian ini menggunakan metode dokumentasi dan metode tes. Metode dokumentasi digunakan untuk memperoleh data tentang banyaknya peserta didik sebagai populasi penelitian, daftar nama-nama peserta didik yang menjadi sampel dan yang terpilih untuk kelas uji coba instrumen, KKM nilai matematika, dll. Metode tes digunakan untuk memperoleh data tentang kemampuan pemecahan masalah peserta didik kelas eksperimen dan kontrol. Tes dengan bobot setara dilakukan sebelum kedua kelas diberikan perlakuan atau disebut pre-test dan sesudah kedua kelas dikenai perlakuan atau disebut dengan post-test. Pre-test dan post-test dilakukan pada kelas eksperimen dan kelas kontrol dengan soal yang sama dan soal berbentuk uraian sebanyak 6 butir soal yang sebelumnya telah diujicobakan. Selanjutnya hasil tes kemampuan pemecahan masalah tersebut diolah dan dianalisis untuk menguji kebenaran hipotesis penelitian.

\section{HASIL DAN DISKUSI}

\section{Hasil}

\section{Pre-Test}

Pre-test dan post-test diikuti oleh 79 peserta didik SMP Negeri 1 Comal yang terdiri dari 39 peserta didik kelas VII A dan 40 peserta didik peserta didik kelas VII B. Hasil analisis deskriptif dari data pre-test tentang kemampuan pemecahan masalah dapat dilihat pada tabel berikut.

Tabel 2. Analisis Deskriptif Pre-test Kemampuan Pemecahan Masalah

\begin{tabular}{|l|c|c|c|c|c|c|}
\hline \multicolumn{1}{|c|}{ Kelas } & $\mathbf{N}$ & $\begin{array}{c}\text { Nilai } \\
\text { Tertinggi }\end{array}$ & $\begin{array}{c}\text { Nilai } \\
\text { Terendah }\end{array}$ & Rata-rata & Varian & $\begin{array}{c}\text { Standar } \\
\text { Deviasi }\end{array}$ \\
\hline Eksperimen & 40 & 63 & 28 & 46,175 & 72,199 & 8,497 \\
\hline Kontrol & 39 & 60 & 25 & 42,692 & 69,797 & 8,354 \\
\hline
\end{tabular}

Berdasarkan tabel 2 diatas dilakukan uji analisis data hasil pre-test kemampuan pemecahan masalah yaitu uji normalitas, uji homogenitas, dan uji kesamaan rata-rata dua pihak yang mempunyai tujuan untuk 
mengetahui keadaan awal dari populasi pada umumnya dan keadaan awal sampel pada khususnya sehingga dapat disimpulkan bahwa sampel berangkat dari titik tolak yang sama atau tidak.

Uji normalitas digunakan untuk mengetahui data pre-test sampel berdistribusi normal atau tidak, dan berpengaruh terhadap uji hipotesis yang digunakan, baik statistik parametrik atau non parametrik. Berdasarkan hasil perhitungan uji normalitas menggunakan rumus Chi Kuadrat, untuk kelas eksperimen diperoleh $\chi_{\text {hitung }}^{2}=2,30$, kelompok kontrol diperoleh $\chi_{\text {hitung }}^{2}=2,81$, dan $\chi_{\text {tabel }}^{2}=7,81$. Karena untuk kedua kelas didapat $\chi_{\text {hitung }}^{2}<\chi_{\text {tabel }}^{2}$ maka $H_{0}$ diterima, artinya data hasil pre-test kelas eksperimen dan kontrol berdistribusi normal.

Uji homogenitas dilakukan untuk mengetahui data pre-test kelas sampel berasal dari populasi yang homogen atau tidak dengan menyelidiki variansnya. Sesuai hasil perhitungan uji homogenitas dengan menggunakan uji Hartley Pearson, diperoleh $F_{\text {hitung }}=1,03$ dan $F_{\text {tabel }}=1,90$. Karena $F_{\text {hitung }}<F_{\text {tabel }}$ maka $\mathrm{H}_{0}$ diterima, artinya varians antara kelas sampel sama sehingga kedua kelas tersebut dikatakan homogen.

Uji kesamaan rata-rata dua pihak digunakan untuk menguji apakah ada kesamaan rata-rata antara kelompok eksperimen dan kelompok kontrol. Berdasarkan hasil perhitungan menunjukkan bahwa $t_{\text {hitung }}=1,84$ dan nilai $t_{\text {tabel }}=1,99$. Karena $t_{\text {tabel }}<t_{\text {hitung }}<t_{\text {tabel }}$ sehingga hipotesis $H_{o}$ diterima, artinya tidak terdapat perbedaan kemampuan pemecahan masalah antara kelas eksperimen dan kontrol.

Dari analisis data pre-test diperoleh bahwa sampel berasal dari populasi yang normal dan homogen serta mempunyai kemampuan pemecahan masalah yang sama, maka dapat disimpulkan sampel berangkat dari titik tolak yang sama. Sehingga kedua kelompok tersebut layak dijadikan sampel dalam penelitian ini yang kemudian hasil penelitian dapat digeneralisasikan untuk populasi dalam penelitian tersebut.

\section{Post-Test}

Hasil analisis deskriptif dari data post-test tentang kemampuan pemecahan masalah dengan menggunakan pendekatan open-ended berbantuan power point pada dapat dilihat pada tabel berikut.

Tabel 3. Analisis Deskriptif Post-test Kemampuan Pemecahan Masalah

\begin{tabular}{|l|c|c|c|c|c|c|}
\hline \multicolumn{1}{|c|}{ Kelas } & $\mathbf{N}$ & $\begin{array}{c}\text { Nilai } \\
\text { Tertinggi }\end{array}$ & $\begin{array}{c}\text { Nilai } \\
\text { Terendah }\end{array}$ & Rata-rata & Varian & $\begin{array}{c}\text { Standar } \\
\text { Deviasi }\end{array}$ \\
\hline Eksperimen & 40 & 95 & 57 & 80,60 & 61,78 & 7,86 \\
\hline Kontrol & 39 & 57 & 25 & 42,69 & 69,79 & 8,35 \\
\hline
\end{tabular}

Sama dengan data pre-test, data post-test diatas dilakukan uji analisis data yaitu uji normalitas, uji homogenitas, dan uji ketuntasan belajar, uji kesamaan rata-rata satu pihak, dan uji gain ternormalisasi.

Uji normalitas dan uji homogenitas data post-test mempunyai cara yang sama dengan uji pada data pre-test. Berdasarkan hasil perhitungan uji normalitas data post-test, untuk kelas eksperimen diperoleh $\chi_{\text {hitung }}^{2}=5,69$, kelompok kontrol diperoleh $\chi_{\text {hitung }}^{2}=4,65$, dan $\chi_{\text {tabel }}^{2}=7,81$. Karena untuk kedua kelas didapat $\chi_{\text {hitung }}^{2}<\chi_{\text {tabel }}^{2}$ maka $H_{0}$ diterima, artinya data hasil post-test kelas eksperimen dan kontrol berdistribusi normal. Sedangkan untuk hasil perhitungan uji homogenitas dengan menggunakan uji Hartley 
Pearson, diperoleh $F_{\text {hitung }}=1,29$ dan $F_{\text {tabel }}=1,90$. Karena $F_{\text {hitung }}<F_{\text {tabel }}$ maka $\mathrm{H}_{0}$ diterima, artinya varians antara kelas sampel sama sehingga kedua kelas tersebut dikatakan homogen.

\section{Uji Ketuntasan Belajar}

Uji ketuntasan belajar dalam penelitian ini digunakan untuk menguji peserta didik yang mencapai KKM individual dan klasikal. Uji ketuntasan belajar menggunakan uji rata-rata pihak kanan untuk menguji ketuntasan belajar individual dan uji proporsi pihak kanan untuk menguji ketuntasan belajar klasikal. Berdasarkan perhitungan dan analisis data uji rata-rata pihak kanan pada kelas eksperimen diperoleh hasil $t_{\text {hitung }}=6,92$, sedangkan pada kelas kontrol $t_{\text {hitung }}=2,28$, dan $t_{\text {tabel }}=1,68$. Karena pada kedua kelas diperoleh $t_{\text {hitung }} \geq t_{\text {tabel }}$ maka $H_{0}$ ditolak artinya rata-rata kemampuan pemecahan masalah peserta didik yang mendapat pembelajaran dengan pendekatan open-ended dengan bantuan power point dan model pembelajaran ekspositori mencapai KKM individual yaitu lebih dari 72. Uji ketuntasan belajar selanjutnya yaitu uji ketuntasan klasikal yang dalam penelitian ini menggunakan uji proporsi pihak kanan. Perhitungan dan analisis data uji proporsi pihak kanan diperoleh hasil yang terlihat pada tabel berikut.

Tabel 4. Hasil Uji Proporsi Pihak Kanan Data Post-test

\begin{tabular}{|l|c|c|c|c|c|c|}
\hline \multicolumn{1}{|c|}{ Kelas } & $\boldsymbol{\Sigma}$ tuntas & $\mathbf{N}$ & $\begin{array}{c}\text { Persentase } \\
\text { Ketuntasan }(\boldsymbol{\pi})\end{array}$ & $\boldsymbol{z}_{\text {hitung }}$ & $-\mathbf{z}_{\text {tabel }}$ & Keterangan \\
\hline Eksperimen & 38 & 40 & $85 \%$ & 1,77 & 1,64 & $H_{0}$ ditolak \\
\hline Kontrol & 31 & 39 & $85 \%$ & $-1,33$ & 1,64 & $H_{0}$ diterima \\
\hline
\end{tabular}

Berdasarkan hasil perhitungan uji ketuntasan klasikal, pada kelas eksperimen diperoleh $z_{\text {hitung }} \geq$ $z_{\text {tabel }}$ maka $H_{0}$ ditolak, artinya rata-rata kemampuan pemecahan masalah pada kelas eksperimen yang mendapat pembelajaran dengan pendekatan open-ended dengan bantuan power point mencapai KKM klasikal. Sedangkan untuk kelas kontrol diperoleh $z_{\text {hitung }}<z_{\text {tabel }}$ maka $H_{0}$ diterima, artinya rata-rata kemampuan pemecahan masalah pada kelas kontrol yang mendapat model pembelajaran ekspositori tidak mencapai KKM klasikal. Jadi dapat disimpulkan bahwa pembelajaran dengan pendekatan open-ended efektif untuk kemampuan pemecahan masalah, sedangkan model pembelajaran ekspositori tidak efektif untuk kemampuan pemecahan masalah.

\section{Uji Kesamaan Rata-Rata (Uji Pihak Kanan)}

Uji kesamaan rata-rata digunakan untuk mengetahui mana yang lebih baik antara kelas yang mendapat pembelajaran dengan open-ended dengan bantuan power point dan kelas yang mendapat model pembelajaran ekspositori. Dalam penelitian ini uji kesamaan rata-rata diuji menggunakan uji kesamaan ratarata pihak kanan. Berdasarkan perhitungan dan analisis data post-test uji kesamaan rata-rata pihak kanan diperoleh hasil $t_{\text {hitung }}=2,83$ dan $t_{\text {tabel }}=1,66$. Hal tersebut menunjukkan bahwa $t_{\text {hitung }} \geq t_{\text {tabel }}$, sehingga hipotesis $H_{0}$ ditolak, artinya rata-rata kemampuan pemecahan masalah kelas yang mendapat pembelajaran dengan pendekatan open-ended dengan bantuan power point lebih dari kelas yang mendapat model pembelajaran ekspositori. Jadi pembelajaran dengan pendekatan open-ended lebih efektif daripada model pembelajaran ekspositori. 


\section{Uji Gain Ternormalisasi}

Uji gain ternormalisasi dilakukan untuk mengetahui peningkatan kemampuan pemecahan masalah antara peserta didik mendapat pembelajaran dengan pendekatan open-ended dengan bantuan power point dengan peserta didik yang mendapat model pembelajaran ekspositori. Menurut Hake (1998) data hasil pretest dan post-test diolah dan dianalis dengan menggunakan rumus indeks gain yaitu

$$
\langle g\rangle \equiv \frac{\%\langle G\rangle}{\%\langle G\rangle_{\max }}=\left(\%\left\langle S_{f}\right\rangle-\%\left\langle S_{i}\right\rangle\right) /\left(100-\%\left\langle S_{i}\right\rangle\right)
$$

Indeks gain ternormalisasi yang diperoleh kemudian diinterpretasikan berdasarkan kategori indeks gain yang dapat dilihat pada tabel 5 sebagai berikut:

Tabel 5. Kategori Indeks Gain Ternormalisasi

\begin{tabular}{|l|c|}
\hline \multicolumn{1}{|c|}{ Rentang } & Kategori \\
\hline Gain $\geq 0,7$ & Tinggi \\
\hline $0.30<$ Gain $<0,70$ & Sedang \\
\hline Gain $\leq 0,30$ & Rendah \\
\hline
\end{tabular}

Hasil interpretasi dan pengolahan data pre-test dan post-test dengan uji gain ternormalisasi dapat dilihat pada tabel berikut.

Tabel 6. Uji Gain Ternormalisasi Data Pre-test dan Post-test

\begin{tabular}{|l|c|c|c|c|l|}
\hline \multicolumn{1}{|c|}{ Kelas } & $\mathbf{N}$ & $\begin{array}{c}\text { Rata-rata } \\
\text { pre-test }\end{array}$ & $\begin{array}{c}\text { Rata-rata } \\
\text { post-test }\end{array}$ & $\begin{array}{c}\text { Rata-rata } \\
\text { indeks gain }\end{array}$ & Interpretasi \\
\hline Eksperimen & 40 & 46,18 & 80,60 & 0,64 & Sedang \\
\hline Kontrol & 39 & 42,69 & 75,26 & 0,56 & Sedang \\
\hline
\end{tabular}

Peningkatan kemampuan pemecahan masalah setelah dilakukan uji gain ternormalisasi, selanjutnya dilakukan uji normalisasi, uji homogenitas, dan uji kesamaan rata-rata pihak kanan. Uji normalitas dan uji homogenitas dilakukan sama seperti data pre-test dan post-test, dari kedua uji tersebut diperoleh hasil bahwa data gain berasal dari populasi yang berdistribusi normal dan homogen. Sehingga uji untuk menentukan peningkatan kemampuan pemecahan masalah mana yang baik antara kelas eksperimen dan kelas kontrol dapat menggunakan uji kesamaan rata-rata pihak kanan. Dari uji tersebut diperoleh bahwa $t_{\text {hitung }}=2,23$ dan $t_{\text {tabel }}=1$,66. Karena bahwa $t_{\text {hitung }} \geq t_{\text {tabel }}$, maka hipotesis $H_{0}$ ditolak, artinya peningkatan kemampuan pemecahan masalah kelas yang mendapat pembelajaran dengan pendekatan open-ended dengan bantuan power point lebih dari kelas yang mendapat model pembelajaran ekspositori.

\section{Diskusi}

Rata-rata kemampuan pemecahan masalah dan peningkatan kemampuan pemecahan masalah peserta didik pada kelas eksperimen lebih baik daripada kelas kontrol. Hal ini dikarenakan pada kelompok eksperimen peserta didik dibimbing untuk berpikir secara kreatif dan matematis dalam memecahkan masalah sesuai dengan pengertian dari pembelajaran open-ended yang dikemukakan oleh Suherman (2003) bahwa pokok pikiran pembelajaran dengan pendekatan open-ended yaitu pembelajaran yang membangun kegiatan pembelajaran yang interaktif antara matematika dan peserta didik sehingga mengundang peserta 
didik untuk menjawab permasalahan dengan berbagai strategi dengan demikian peserta didik mampu mempertimbangkan keberhasilan dan kegagalan proses belajar, mencari tahu apa yang sudah dikerjakan dan apa yang tidak, serta apa yang perlu diperbaiki sehingga mampu meningkatkan kemampuan pemecahan masalah peserta didik.

Pada pertemuan-pertemuan dalam kelompok eksperimen, penerapan pembelajaran dengan pendekatan open-ended dengan bantuan power point memiliki unsur-unsur fase yang membuat siswa lebih aktif, kreatif dan lebih dapat memahami materi. Guru tidak sekadar memberikan pengetahuan kepada siswa, melainkan memfasilitasi siswa untuk membangun pengetahuannya sendiri sehingga siswa memiliki pemecahan masalah yang lebih mantap. Kegiatan pembelajaran membawa peserta didik dalam menjawab permasalahan dengan banyak cara dan banyak jawaban (yang benar) sehingga mengundang potensi intelektual dan pengalaman peserta didik dalam proses menemukan sesuatu yang baru. Selain itu media power point sangat mendukung peserta didik dalam mengkonstruk pengetahuannya dalam gambar-gambar berbentuk visual dan juga sebagai media penghubung antara guru dan peserta didik di masa pandemi.

Beberapa studi telah mengkaji tentang pembelajaran dengan pendekatan open-ended, Yulita, Suyitno, \& Sugiman (2013) mengkaji bahwa pembelajaran matematika dengan pendekatan open-ended efektif dalam meningkatkan kemampuan pemecahan masalah dengan mengguunakan CD pembelajaran. Selain itu Faridah, Isrok'atun, \& Aeni (2016) mencoba mengkaitkan bahwa pendekatan open-ended dapat meningkatkan kemampuan berpikir kreatif matematis dan kepercayaan diri peserta didik SD di Kabupaten Sumedang. Husniah, Maulana, \& Isrok'atun (2017) mengemukakan bahwa pendekatan open-ended mempunyai pengaruh positif terhadap kemampuan pemecahan masalah matematis dan motivasi belajar peserta didik kelas V SD di Kabupaten Majalengka. Penerapan open-ended pada pembelajaran matematika juga dijadikan penelitian oleh Astin, \& Bharata (2016) dimana disimpulkan bahwa pendekatan open-ended merupakan salah satu upaya yang dapat digunakan untuk meningkatkan kemampuan representasi matematis peserta didik. Sementara Septiani \& Zanthy (2019) telah mengkaji bahwa terdapat peningkatan kemampuan pemahaman konsep matematik peserta didik MTs melalui pendekatan open-ended. Dari beberapa literatur penelitian diatas, pendekatan open-ended pada penelitian ini juga dapat meningkatkan kemapuan pemecahan masalah peserta didik dimana dibantu dengan power point sebagai media penunjang kegiatan pembelajaran matematika secara daring di masa pandemi atau mewabahnya virus Covid-19.

\section{KESIMPULAN}

Dari hasil uji kesamaam rata-rata (uji pihak kanan) yang menunjukkan bahwa $t_{\text {hitung }} \geq t_{\text {tabel }}$, sehingga hipotesis $H_{0}$ ditolak, artinya pembelajaran matematika dengan pendekatan open-ended dengan bantuan power point lebih efektif untuk kemampuan pemecahan masalah daripada model pembelajaran ekspositori. Selain uji diatas, terdapat juga uji gain yang telah ternomalisasi dimana $t_{\text {hitung }} \geq t_{\text {tabel }}$, maka hipotesis $H_{0}$ juga ditolak, yang artinya peningkatan kemampuan pemecahan masalah kelas yang mendapat pembelajaran dengan pendekatan open-ended dengan bantuan power point lebih baik daripada kelas yang mendapat model pembelajaran ekspositori. 
Dalam proses belajar mengajar matematika, guru sebaiknya menerapkan pembelajaran dengan pendekatan open-ended dikarenakan pembelajaran open-ended sangat sesuai dengan karakteristik matematika yang didalamnya terdapat proses pemecahan masalah serta dapat meningkatkan kreatifitas, pola pikir matematis, dan potensi intelektual peserta didik. Pendekatan open-ended akan membiasakan peserta didik untuk berpikir tingkat tinggi dalam mengerjakan soal-soal non rutin yang selama ini jarang disentuh dalam proses pembelajaran matematika dimana dapat mempengaruhi dalam memecahkan masalah dalam kehidupan sehari-hari. Penggunaan power point juga diperlukan karena sesuai dengan kemajuan teknologi yang dapat membuat anak tidak jenuh dengan pembelajaran yang monoton serta sebagai motivasi peserta didik untuk belajar.

\section{UCAPAN TERIMA KASIH}

Terimakasih kepada Ibu Umi Tri Waluyati, S.Pd selaku guru pamong kelas VII, serta seluruh peserta didik kelas VII SMP Negeri 1 Comal Kabupaten Pemalang yang sudah memberi dukungan, izin, dan turut berpatisipasi dalam terlaksananya penelitian ini.

\section{REFERENSI}

Allen, C. E., Froustet, M. E., LeBlanc, J. F., Payne, J. N., Priest, A., Reed, J. F., Worth, J. E., Thomason, G. M., Robinson, B., \& Payne, J. N. (2020). Executive Summary Principles and Standards for School Mathematics. In National Council of Teachers of Mathematics (Vol. 29, Issue 5). https://doi.org/10.5951/at.29.5.0059

Astin, A. E., \& Bharata, H. (2016). Penerapan Pendekatan Open-Ended dalam Pembelajaran Matematika terhadap Kemampuan Representasi Matematis Siswa. Prosiding: Konferensi Nasional Penelitian Matematika Dan Pembelajarannya (KNMP 1) UMS, 20, 631-639.

Emilya, D., Darmawijoyo, D., \& Ilma, R. (2013). Pengembangan Soal-Soal Open-Ended Materi Lingkaran Untuk Meningkatkan Penalaran Matematika Siswa Kelas Viii Sekolah Menengah Pertama Negeri 10 Palembang. Jurnal Pendidikan Matematika, 4(2). https://doi.org/10.22342/jpm.4.2.316.

Faridah, N., \& Aeni, A. N. (2016). Pendekatan Open-Ended Untuk Meningkatkan Kemampuan Berpikir Kreatif Matematis Dan Kepercayaan Diri Siswa. Jurnal Pena Ilmiah, 1(1), 1061-1070. https://doi.org/10.23819/pi.v1i1.3025

Hawa, S. (2014). Teori Belajar Bruner. In Pembelajaran Matematika Sekolah Dasar. http://staff.uny.ac.id/sites/default/files/PengembanganPembelajaranMatematika_UNIT_1_0.pdf

Hendriani, M., Melindawati, S., \& Mardicko, A. (2021). Keterampilan Pemecahan Masalah Matematika di Era Revolusi Industri 4.0 Siswa SD. Jurnal Cendekia : Jurnal Pendidikan Matematika, 5(2), 892-899. https://doi.org/10.31004/cendekia.v5i2.477

Hudojo, H. (2005). Pengembangan kurikulum dan pembelajaran matematika. Malang: UM Press.

Husniah, G. N., Maulana, M., \& Isrok'atun, I. (2017). Pengaruh Pendekatan Open-Ended Terhadap Kemampuan Pemecahan Masalah Matematis Dan Motivasi Belajar. Jurnal Pena Ilmiah, 2(1), 841850. https://doi.org/10.17509/jpi.v2i1.11220

Polya, G. (2004). How to solve it: A new aspect of mathematical method (Vol. 85). Princeton university press. 
Pusat Penilaian Pendidikan, K. (2019). Laporan Hasil Ujian Nasional Tahun 2019. Jakarta: BalitbangKemendiknas.

Rifa'i, A., \& Anni, C. T. (2012). Psikologi pendidikan. In Semarang: Pusat Pengembangan MKU/MKDKLP3 Unnes.

Septiani, U., \& Zanthy, L. S. (2019). Pembelajaran Matematika Melalui Pendekatan Open-Ended Terhadap Pemahaman Matematik Siswa MTs. Jurnal Cendekia : Jurnal Pendidikan Matematika, 3(1), 58-63. https://doi.org/10.31004/cendekia.v3i1.75

Sugiyono. (2014). Metode Penelitian Pendidikan Pendekatan Kuantitatif, Kuantitatif, dan R\&D. In A. Bandung (Ed.), Bandung: Alfabeta. Alfabeta Bandung.

Suherman, E. (2003). Strategi pembelajaran matematika kontemporer. Bandung: Jica.

Syaodih Sukmadinata, N. (2007). Metode penelitian pendidikan. In Bandung: Remaja Rosda Karya.

Widodo, D. (2017). Metodologi penelitian populer \& praktis. Jakarta: PT RajaGrafindo Persada.

World Health Organization. (2021). WHO-convened Global Study of Origins of SARS-CoV-2 : China Part (14 January-10 February 2021). In Joint WHO-China Study Team report (Issue February).

Yulita, T., Suyitno, H., \& Sugiman. (2013). Keefektifan Pembelajaran Matematika Pendekatan OpenEnded Berbantuan CD Untuk Meningkatkan Kemampuan. Universitas Negeri Semarang. 